\title{
Metastasis from renal cell carcinoma to the parotid gland: Rare but catastrophic event!
}

\author{
Rahul Janak Sinha, Swarnendu Mandal, Vishwajeet Singh \\ Department of Urology, CSMMU (Chhatrapati Shahuji Maharaj Medical University), (formerly King George's Medical University \\ [K.G.M.U.]), Lucknow-226003, India.
}

Corresponding author: Dr Rahul Janak Sinha, MS (General Surgery), MCh (Urology), Assistant Professor, Department of Urology, CSMMU (formerly KGMU), Lucknow, India. Phone no. +919415003051 E-mail: rahuljanaksinha@rediffmail.com; rahuljanaksinha@yahoo.co.in

Received: 2011-07-07

DOI : $10.5430 /$ jst.v1n3p150

\author{
Accepted: 2011-09-12 \\ URL: http://dx.doi.org/10.5430/jst.v1n3p150
}

\section{Abstract:}

We present the case of a male aged 35 years, who complained of painful hematuria and passage of blood clots since 4-5 months. This was associated with abdominal lump in the right lumbar area since 2 months. The patient noticed an ulcerative growth in the left gingivo-buccal sulcus 1 month back and also developed a swelling in the left parotid region around the same time. The parotid swelling started increasing in size at an alarming rate. After proper evaluation of the patient along with radiological and histopathological investigations, he was diagnosed as having renal cell carcinoma (RCC) with metastasis to the left parotid gland. RCC metastasizing to the parotid gland is an extremely rare and catastrophic event. To the best of our knowledge, this is the first such case report from India.

\section{Keywords:}

Carcinoma, renal cell; Parotid gland; Neoplasm metastasis

\section{NTRODUCTI ON}

Malignant neoplasms account for $15 \%-35 \%$ of all parotid gland tumors; $21 \%-42 \%$ of these tumors are due to metastatic processes. ${ }^{1}$ Metastases to the parotid gland often originates from melanoma or squamous cell carcinoma of the head and neck. ${ }^{2}$ Literature identifies approximately 26 cases of renal cell carcinoma (RCC) with metastasis to the parotid gland; in most of these patients multiple metastases was the norm, solitary parotid location is extremely rare. ${ }^{3-6}$ In 14 of these patients, parotid metastasis was the initial clue to malignancy in the kidney, while, in 12 patients, parotid metastasis occurred after the primary treatment of RCC (time interval ranged from months to years). ${ }^{3-6}$

Herein, we present a case of RCC with synchronous metastasis to the parotid gland. To the best of our knowledge and belief, this is first such case report from India.

\section{CASE PRESENTATION}

A male aged 35 years, presented to our outdoor patient department with complaints of intermittent, painful hematuria and passage of blood clots since 4-5 months. It was associated with abdominal lump in the right lumbar area since 2 
months. The lump was gradually increasing in size. The patient had significant loss of weight and appetite since last 3 months; this was also associated with altered bowel habits.

He noticed an ulcerative growth in the left gingivo-buccal sulcus 1 month back. Biopsy of the ulcer margin revealed it as mucocele. He also developed a swelling in the left parotid region around the same time which started increasing in size at an alarming rate (Figure 1). Ultrasonography with color Doppler of the abdomen showed a large well defined heterogeneous space occupying lesion (SOL) in the right renal fossa, suggestive of RCC; inferior vena cava thrombus was not detected. Contrast enhanced computerized tomography (CECT) scan of the abdomen revealed a large well defined heterogeneously enhancing right renal mass $(16 \mathrm{~cm} \times 12 \mathrm{~cm})$ with internal necrosis. This mass was involving the vascular pedicle; perinephric fat stranding and adjacent mass effect was also noticed (Figure 2A). Magnetic Resonance Imaging (MRI) of the abdomen also depicted a well defined heterogeneously enhancing SOL in the right kidney with no tumor thrombus (Figure 2B). CT scan of the head and neck showed a bulky and heterogeneous left parotid gland extending into the nasopharynx and displacing its lateral wall medially, suggesting neoplastic involvement (Figure 3). Fine needle aspiration cytology of the parotid swelling revealed it as metastatic clear cell adenocarcinoma with renal tubule formation.

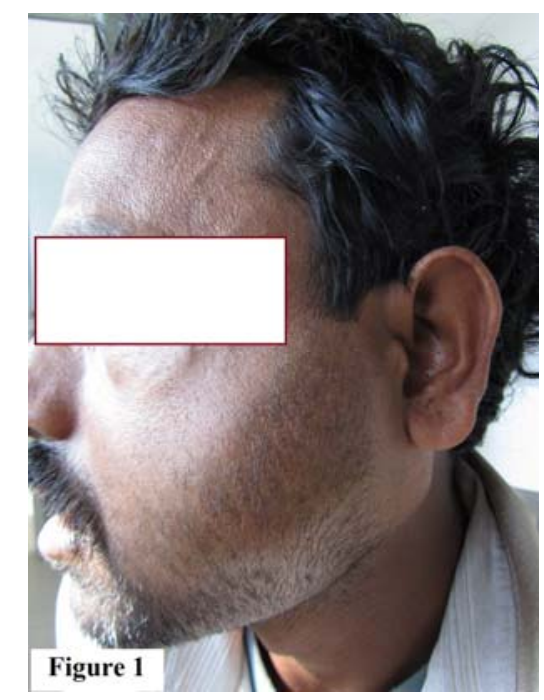

Figure 1 Photograph (lateral view) depicting the swelling in the left parotid region.

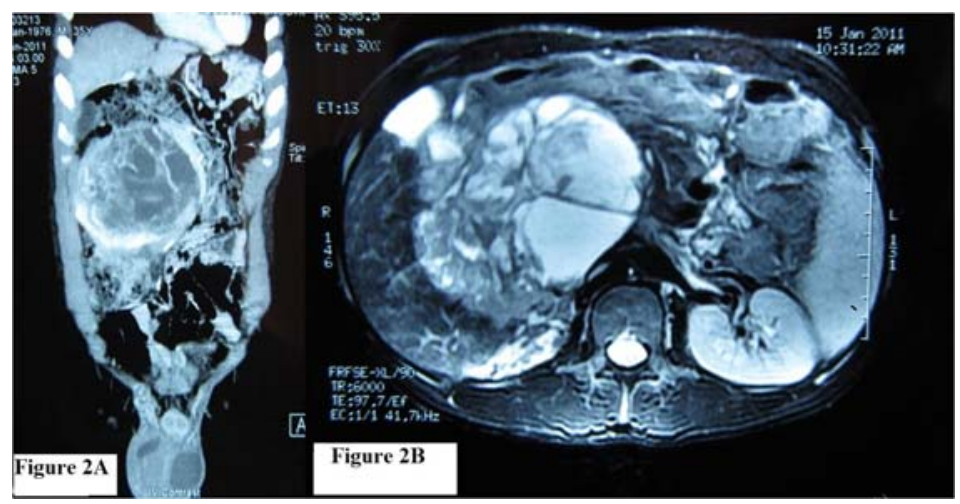

Figure 2 A. CT scan depicting the right renal mass (sagittal section). B. MRI showing the heterogeneously enhancing right renal mass (transverse section). 




Figure 3 CT scan showing the bulky left parotid gland.

\section{SCUSSI ON}

The most common sites where RCC metastasize are lungs, lymph node, long bones, liver, adrenal, contralateral kidney and brain. ${ }^{1}$ RCC is known to have a diverse metastatic potential and may involve almost any organ e.g. thyroid, penis, heart or skin. ${ }^{7,8}$ According to different series, RCC rarely metastasizes to the maxillofacial area (range $5 \%-15 \%$ ). ${ }^{9-11}$ However, RCC metastasizing to the parotid gland is still an extremely rare event (seen in $0.5 \%$ of cases). ${ }^{12}$

One theory states that lymphatic spread of RCC through the thoracic duct may account for the high incidence of lymph node involvement of the head and neck. However, another theory postulates that tumor emboli spread through Batson paravertebral venous plexus, bypassing the pulmonary vascular filtration. ${ }^{3}$ RCC is highly vascular and associated with multiple arteriovenous shunts; it is probable that through these mechanisms RCC reaches the parotid gland and other extranodal sites of the head and neck. ${ }^{13}$ Hematogenous spread usually involves the interlobular and intralobular fibrous septa of the parotid gland and then extends into the parenchyma secondarily. ${ }^{14}$

The most common presenting complaint in patients with parotid gland involvement is a parotid mass; some of these patients also complain regarding pain and tenderness. Significant numbers of patients have a pulsatile mass with bruit, requiring an arteriographic study as well. In these cases, the differential diagnoses may include an arteriovenous fistula or arterial aneurysmal disease. ${ }^{15}$ Most patients with RCC have gross hematuria; other symptoms include costovertebral pain and a palpable mass in the flank. Some tumors may remain asymptomatic till they become quite large. Fever, malaise, weakness, weight loss and other constitutional symptoms may also manifest.

Radiological findings tend to be indistinguishable from those of a primary malignant neoplasm. ${ }^{16}$ Use of periodic-acid Schiff (PAS) and enzymes such as diastase, are helpful in distinguishing primary submaxillary gland tumors such as acinic cell and mucoepidermoid carcinoma from RCC. ${ }^{12,17}$ RCC contains glycogen, making it PAS-positive and diastase-negative. On the other hand, acinic cell cancer and mucoepidermoid cancer are revealed as PAS-positive and contain diastase-resistant material. ${ }^{10,17}$ RCC stains positive for lipids. ${ }^{12}$ Additionally, RCC shows positive immunohistochemical staining with keratin and vimentin and negative response with carcinoembryonic antigen. ${ }^{10,18}$ Histopathological finding of malignant clear cell tumor in a parotidectomy specimen involves the differential diagnosis of clear cell primary parotid tumors and other uncommon metastases from the kidney, liver, large bowel, prostate, and 
thyroid. ${ }^{19}$ Typical histologic features of RCC of clear cell type consists of highly vascularized sheets, cords and tubular aggregates of tumor cells with abundant clear cytoplasm.

Treatment of localized RCC usually is radical nephrectomy, which remains the only potentially curative therapy available as of now. For metastatic disease; radiotherapy, chemotherapy, and hormonal therapy have been tried. Newer techniques and modalities include interferon, interleukin-2, and genetically modified tumor vaccines.

Because of dismal results with adjunctive therapy, an aggressive surgical approach has been advocated for patients with RCC having solitary metastasis. Forty patients who underwent removal of metastatic focus due to RCC, 13 (33\%) survived longer than 5 years. ${ }^{20}$ In patients with solitary parotid metastasis, one should consider parotidectomy with preservation of the facial nerve. ${ }^{7}$

Our patient was advised radical nephrectomy followed by parotidectomy in a staged manner. Due to the overall poor prognosis of this entity and the poor health of the patient; he and his attendants declined any form of treatment (surgical or medical) and opted for palliative care at home. The patient succumbed to his disease after approximately two months (as per the telephonic information obtained from his relatives).

\section{CONCLUSI ON}

Parotid metastasis from RCC is an extremely rare and lethal phenomenon. Parotidectomy (with preservation of the facial nerve, if possible) along with radical nephrectomy is the only possible therapeutic modality which might enhance the survival of such patients.

\section{Conflicting interest: None}

\section{REFERENCES}

[1] Vara A, Madrigal B, Pérez del Río MJ, Díaz A, Mateos A, Sales C. Parotid metastasis from renal clear cell adenocarcinoma. An unusual site for metastasis. Urol Int. 1998;61(3):196-198. http://dx.doi.org/10.1159/000030308 PMid:9933847

[2] Seifert G, Hennings K, Caselitz J. Metastatic tumors to the parotid and submandibular glands--analysis and differential diagnosis of 108 cases. Pathol Res Pract. 1986 Dec;181(6):684-692. PMid:3562340

[3] Park YW, Hlivo TJ. Parotid gland metastasis from renal cell carcinoma. Laryngoscope 2002;112:453-456. http://dx.doi.org/10.1097/00005537-200203000-00009 PMid:12148853

[4] Kundu S, Eynon-Lewis NJ, Radcliffe GJ. Extensive metastatic renal cell carcinoma presenting as facial nerve palsy. J Laryngol Otol. 2001 Jun;115(6):488-490. http://dx.doi.org/10.1258/0022215011908009

[5] Saitoh H. Distant metastasis of renal adenocarcinoma. Cancer. 1981 Sep 15;48(6):1487-1491. http://dx.doi.org/10.1002/1097-0142(19810915)48:6<1487::AID-CNCR2820480635>3.0.CO;2-9

[6] Göğüş C, Kiliç O, Tulunay O, Tulunay O, Bedük Y. Solitary metastasis of renal cell carcinoma to the parotid gland 10 years after radical nephrectomy. Int J Urol. 2004 Oct;11(10):894-896. http://dx.doi.org/10.1111/j.1442-2042.2004.00902.x PMid:15479296

[7] Spreafico R, Nicoletti G, Ferrario F, Scanziani R, Grasso M. Parotid metastasis from renal cell carcinoma: a case report and review of the literature. Acta Otorhinolaryngol Ital. 2008 Oct;28(5):266-268. PMid:19186459 PMCid:2689528

[8] Seijas BP, Franco FL, Sastre RM, García AA, López-Cedrún Cembranos JL. Metastatic renal cell carcinoma presenting as a parotid tumor. Oral Surg Oral Med Oral Pathol Oral Radiol Endod. 2005 May;99(5):554-557. http://dx.doi.org/10.1016/j.tripleo.2004.08.007 PMid:15829877

[9] Günbay MU, Ceryan K, Küpelíoğlu AA. Metastatic renal carcinoma to the parotid gland. J Laryngol Otol. 1989 Apr;103(4):417-418. PMid:2715700

[10] Moudouni SM, Tligui M, Doublet JD, Haab F, Gattegno B, Thibault P. Late metastasis of renal cell carcinoma to the submaxillary gland 10 years after radical nephrectomy. Int J Urol. 2006 Apr;13(4):431-432. http://dx.doi.org/10.1111/j.1442-2042.2006.01318.x PMid:16734864

[11] Madison JF, Frierson HF Jr. Pathologic quiz case 2. Clear cell carcinoma, consistent with metastatic renal cell carcinoma. Arch Otolaryngol Head Neck Surg. 1988 May;114(5):570-571, 573. 
[12] Pisani P, Angeli G, Krangli M, Pia F. Renal carcinoma metastasis to the parotid gland. J Laryngol Otol 1990;104:352-354. http://dx.doi.org/10.1017/S0022215100112691

[13] Nahum AM, Bailey BJ. Malignant tumors metastatic to the paranasal sinuses: Case report and review of the literature. Laryngoscope. 1963 Jul;73:942-953. PMid:14043146

[14] Batsakis JG. Pathology consultation. Parotid gland and its lymph nodes as metastatic sites. Ann Otol Rhinol Laryngol. 1983 Mar-Apr;92(2 Pt 1):209-210. PMid:6838114

[15] Coppa GF, Oszczakiewicz M. Parotid gland metastasis from renal carcinoma. Int Surg. 1990 Jul-Sep;75(3):198-202. PMid:2242976

[16] Som PM, Norton KI, Shugar JM, Reede DL, Norton L, Biller HF, Som ML. Metastatic hypernephroma to the head and neck. AJNR Am J Neuroradiol. 1987 Nov-Dec;8(6):1103-1106. PMid:3120536

[17] Owens RM, Friedman CD, Becker SP. Renal cell carcinoma with metastasis to the parotid gland: case reports and review of the literature. Head Neck. 1989 Mar-Apr;11(2):174-178. http://dx.doi.org/10.1002/hed.2880110212

[18] Melnick SJ, Amazon K, Dembrow V. Metastatic renal cell carcinoma presenting as a parotid tumor: a case report with immunohistochemical findings and a review of the literature. Hum Pathol. 1989 Feb;20(2):195-197. http://dx.doi.org/10.1016/0046-8177(89)90186-X

[19] Maiorano E, Altini M, Favia G. Clear cell tumors of the salivary glands, jaws, and oral mucosa. Semin Diagn Pathol. 1997 Aug;14(3):203-212. PMid:9279976

[20] Skinner DG, Colvin RB, Vermillion CD, Pfister RC, Leadbetter WF. Diagnosis and management of renal cell carcinoma. A clinical and pathologic study of 309 cases. Cancer. 1971 Nov;28(5):1165-1177. http://dx.doi.org/10.1002/1097-0142(1971)28:5<1165::AID-CNCR2820280513>3.0.CO;2-G

\section{ABBREVIATIONS:}

$\mathrm{RCC}=$ renal cell carcinoma

$\mathrm{SOL}=$ space occupying lesion

CECT $=$ contrast enhanced computerized tomography

MRI = magnetic resonance imaging

PAS $=$ periodic-acid Schiff 